\title{
Paenibacillus terrigena sp. nov., isolated from soil
}

Correspondence

Cheng-Hui Xie

cxie@uams.edu

\author{
Cheng-Hui Xie and Akira Yokota \\ Institute of Molecular and Cellular Biosciences, The University of Tokyo, 1-1-1 Yayoi, \\ Bunkyo-Ku, Tokyo 113-0032, Japan
}

\begin{abstract}
A novel Gram-positive bacterium, strain $\mathrm{A} 35^{\top}$, was isolated from coastal soil at Chiba, Japan, and was identified as a member of the genus Paenibacillus on the basis of phenotypic and phylogenetic analyses. The bacterium was found to be a facultatively anaerobic and endospore-forming rod. The predominant menaquinone was MK-7, the major cellular fatty acid was anteiso- $C_{15: 0}$ and the DNA G + C content was 48.1 mol\%. The levels of $16 \mathrm{~S}$ rRNA gene sequence similarity between strain $A 35^{\top}$ and Paenibacillus species with validly published names were less than $94 \%$. Strain $\mathrm{A} 35^{\top}$ was clearly distinguishable from reference species for the genus Paenibacillus. Therefore, on the basis of these data, a novel species of the genus Paenibacillus, Paenibacillus terrigena sp. nov., is proposed. The type strain is $A 35^{\top}\left(=\right.$ IAM $15291^{\top}=$ CCTCC AB206026 $\left.^{\top}\right)$.
\end{abstract}

The genus Paenibacillus (Ash et al., 1993), which comprises aerobic or facultatively anaerobic endospore-forming bacilli, is phenotypically related to other genera belonging to the family Bacillaceae. Phylogenetic analysis based on $16 \mathrm{~S}$ rRNA gene sequences is the most useful method for identifying Paenibacillus species and differentiating them from other members of the family Bacillaceae. The genus currently contains 69 recognized species and the type species is Paenibacillus polymyxa. During the screening of nitrogenfixing bacteria in a coastal soil sample from Chiba, Japan, a novel Gram-positive bacterium, designated strain $\mathrm{A} 35^{\mathrm{T}}$, was isolated. Strain $\mathrm{A} 35^{\mathrm{T}}$ neither fixes nitrogen nor possesses the nifH gene (Xie \& Yokota, 2006). On the basis of $16 \mathrm{~S}$ rRNA gene sequence analysis, strain $\mathrm{A} 35^{\mathrm{T}}$ showed a very low level of similarity (92\%) to the type species of the genus Paenibacillus, $P$. polymyxa. The next most closely related species were Paenibacillus koreensis (GenBank accession no. AF130254), Paenibacillus larvae (X60619) and Paenibacillus validus (AB073203), which showed approximately $94 \% 16 \mathrm{~S}$ rRNA gene sequence similarity to strain $\mathrm{A} 35^{\mathrm{T}}$. In comparisons with other recognized species of the genus Paenibacillus, the novel strain showed less than $94 \%$ similarity. To elucidate the taxonomic position of strain $\mathrm{A} 35^{\mathrm{T}}$, we used a polyphasic taxonomic approach that included physiological tests and analyses of the fatty acid content, quinone system, DNA $\mathrm{G}+\mathrm{C}$ content and 16S rRNA gene sequence. On the basis of the phenotypic and phylogenetic analyses, it is proposed that strain $\mathrm{A} 35^{\mathrm{T}}$ represents a novel species of the genus Paenibacillus.

Strain $\mathrm{A} 35^{\mathrm{T}}$ was incubated in nutrient broth (NB; Difco) at $29^{\circ} \mathrm{C}$. Cell morphology and motility were examined by phase-contrast microscopy (BX60; Olympus). Growth

The GenBank/EMBL/DDBJ accession number for the 16S rRNA gene sequence of strain $A 35^{\top}$ is $A B 248087$. under anaerobic growth conditions was determined after 2 weeks incubation in an AnaeroPack (Mitsubishi Gas Chemical Co.). Gram staining was performed using 3\% $\mathrm{KOH}$. Catalase activity was determined using $3 \% \mathrm{H}_{2} \mathrm{O}_{2}$ with the production of bubbles indicating a positive result. Oxidase was determined using cytochrome oxidase paper (Nissui Pharmaceutical Co.). API 20E and API $50 \mathrm{CH}$ microtest galleries (bioMérieux) were used to determine physiological and biochemical characteristics. API strips were incubated for 2 days at $30^{\circ} \mathrm{C}$. Tolerance of salinity was determined by inoculating cells into NB supplemented with $0-4.0 \% \mathrm{NaCl}(\mathrm{w} / \mathrm{v})$. For fatty acid analysis, cells were incubated on trypticase soy agar medium (Becton Dickinson) for 3 days at $29^{\circ} \mathrm{C}$. Cellular fatty acid methyl esters were prepared, separated and identified by using the Microbial Identification System (Microbial ID). Cells used to determine the respiratory quinone system and the DNA $\mathrm{G}+\mathrm{C}$ content were incubated in NB for 5 days at $29^{\circ} \mathrm{C}$ and then characterized by HPLC (Shimadzu) as described by Xie \& Yokota (2003). Genomic DNA was isolated according to the method of Marmur (1961) using cells cultured for 2 days in NB. An acetylene-reduction assay and growth in nitrogen-free medium were used to determine nitrogenase activity (Xie \& Yokota, 2006).

A fragment (approx. $1500 \mathrm{bp}$ ) of the $16 \mathrm{~S}$ rRNA gene sequence was amplified by a PCR and sequenced as described by Xie \& Yokota (2003). The $16 \mathrm{~S}$ rRNA gene sequences obtained in this study and from GenBank were aligned using the CLUSTAL W software package (Thompson et al., 1994), and the evolutionary distances and the $K_{\text {nuc }}$ value (Kimura, 1980) were generated. Alignment gaps and ambiguous bases were excluded from the calculation. A phylogenetic tree based on a comparison of 1189 bases was constructed using the neighbour-joining method (Saitou \& Nei, 1987). The topology of the tree was evaluated by using 
the bootstrap resampling method of Felsenstein (1985) with 1000 replicates. Similarity values were calculated using PAUP, version 4.0b1 (Swofford, 1998).

The 16S rRNA gene sequence search using BLAST revealed that strain $\mathrm{A} 35^{\mathrm{T}}$ exhibited very low levels of similarity (not more than $94 \%$ ) with respect to the recognized species of Paenibacillus, which is sufficient to indicate that strain $\mathrm{A} 35^{\mathrm{T}}$ represents a novel member of the genus (Stackebrandt \& Goebel, 1994). The phylogenetic tree (Fig. 1) showed that strain $\mathrm{A} 35^{\mathrm{T}}$ was affiliated to the genus Paenibacillus but was not closely related to any other species as poor bootstrap support (less than $60 \%$ ) was found at the branch node.

Chemotaxonomic analysis also supported the view that strain $\mathrm{A} 35^{\mathrm{T}}$ was a member of the genus Paenibacillus (Ash et al., 1993). The presence of MK-7 as the major quinone system, the G+C DNA content (48.1 mol\%) and the presence of anteiso- $\mathrm{C}_{15: 0}$ as the major fatty acid (56.4-57.1\%) reflected the similarity of strain $\mathrm{A} 35^{\mathrm{T}}$ to all members of the genus Paenibacillus (Shida et al., 1997). The fatty acid contents of the novel strain and the type strains of selected Paenibacillus species are shown in Table 1. Phenotypic differences between strain $A 35^{\mathrm{T}}$ and the reference strains are shown in Table 2.
In summary, on the basis of the phylogenetic and phenotypic analyses, strain $\mathrm{A} 35^{\mathrm{T}}$ can be classified as representing a novel species of the genus Paenibacillus, for which we propose the name Paenibacillus terrigena.

\section{Description of Paenibacillus terrigena}

Paenibacillus terrigena [ter.ri.ge'na. L. n. terra soil; L. v. gignere to bear; L. n. terrigena (nominative in apposition) born of, or from, the earth, earth-born].

Cells are Gram-positive. Vegetative cells are motile rods; terminal, oval spores can be observed within swollen sporangia. Facultatively anaerobic. Grows at $4-32{ }^{\circ} \mathrm{C}$, $\mathrm{pH} 4.0-10.0$ and $3.5 \% \mathrm{NaCl}$. Shows poor growth in carbohydrate-containing media (determined on $\mathrm{O} / \mathrm{F}$ basal medium; Xie \& Yokota, 2006), but grows well in LuriaBertani and trypticase soy agar media, producing irregular, smooth, cream-coloured colonies. Catalase-, oxidase- and $\beta$-galactosidase-positive. Gives a positive result for nitrate reduction, aesculin hydrolysis and in the Voges-Proskauer test. Acid is produced from glucose, sucrose, melibiose and amygdalin. Glucose, glycerol, ribose, D-xylose, amygdalin, arbutin, methyl $\beta$-D-xyloside, galactose, methyl $\alpha$-D-mannoside, methyl $\alpha$-D-glucoside, aesculin, salicin, cellobiose,

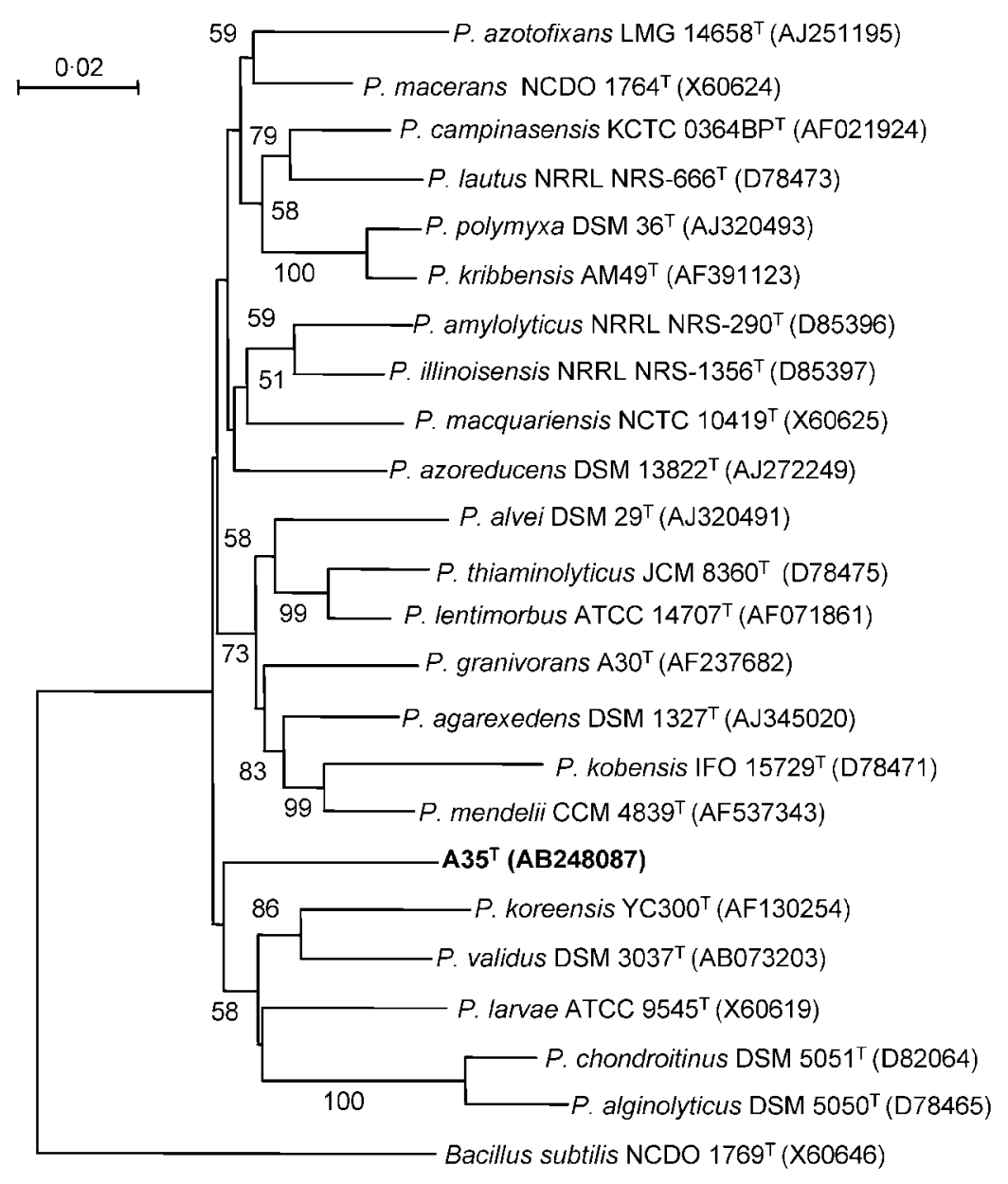

Fig. 1. Neighbour-joining tree, based on 16S rRNA gene sequences, showing the phylogenetic position of strain $A 35^{\top}$ within the genus Paenibacillus. Bacillus subtilis NCDO $1769^{\top}$ was used as the outgroup. Numbers at the nodes indicate the percentages of occurrence in 1000 bootstrapped trees; only values greater than $50 \%$ are shown. Bar, 0.02 substitutions per nucleotide position. 
Table 1. Cellular fatty acids (\%) of strain $\mathrm{A} 35^{\top}$ and some type strains in the genus Paenibacillus

Strains: $1, \mathrm{~A} 35^{\mathrm{T}} ; 2$, P. polymyxa DSM $36^{\mathrm{T}} ; 3$, P. larvae NBRC $15408^{\mathrm{T}}$; 4, P. validus DSM $3037^{\mathrm{T}}$; 5, Paenibacillus chondroitinus DSM $5051^{\mathrm{T}}$. All of the data (except those for strain $\mathrm{A} 35^{\mathrm{T}}$ ) are from Shida et al. (1997).

\begin{tabular}{|lccccc|}
\hline Fatty acid & $\mathbf{1}$ & $\mathbf{2}$ & $\mathbf{3}$ & $\mathbf{4}$ & $\mathbf{5}$ \\
\hline $\mathrm{C}_{14: 0}$ & 0.8 & 0.4 & 0.6 & 0.7 & 0.9 \\
$\mathrm{C}_{15: 0}$ & $3.8-4.1$ & 0.3 & 1.3 & 1.4 & 2.0 \\
$\mathrm{C}_{16: 0}$ & $4.0-4.4$ & 9.3 & 6.4 & 10.8 & 6.4 \\
$\mathrm{C}_{16: 1} \omega 11 c$ & 1.0 & - & 0.8 & 0.4 & - \\
anteiso- $\mathrm{C}_{13: 0}$ & 0.3 & - & - & - & 0 \\
iso- $\mathrm{C}_{14: 0}$ & 2.6 & 0.5 & 0.2 & 1.4 & 1.7 \\
iso- $\mathrm{C}_{15: 0}$ & $5.7-5.8$ & 1.0 & 9.5 & 4.1 & 2.4 \\
anteiso-C $15: 0$ & $56.4-57.1$ & 62.9 & 48.8 & 57.3 & 69.7 \\
iso-C $16: 0$ & 13.0 & 5.6 & 5.3 & 11.7 & 10.4 \\
iso- $\mathrm{C}_{17: 0}$ & $1.9-2.1$ & 1.6 & 4.5 & 3.4 & 0.7 \\
anteiso- $\mathrm{C}_{17: 0}$ & $7.9-8.1$ & 16.9 & 0.7 & 7.5 & 3.2 \\
\hline
\end{tabular}

Table 2. Distinctive phenotypic properties of strain $A 35^{\top}$ and reference strains of Paenibacillus

Strains: 1, P. koreensis $\mathrm{YC}_{000}^{\mathrm{T}}$; 2, P. polymyxa ATCC $842^{\mathrm{T}} ; 3, P$. validus DSM $3037^{\mathrm{T}} ; 4$, P. larvae DSM $7030^{\mathrm{T}}$; 5, Paenibacillus alginolyticus DSM $5050^{\mathrm{T}} ; 6, \mathrm{~A} 35^{\mathrm{T}}$. Data for reference species are from Chung et al. (2000) and Yoon et al. (2002). +, Positive; -, negative; $\mathrm{V}$, variable reaction; $\mathrm{w}$, weak reaction; ND, not determined.

\begin{tabular}{|c|c|c|c|c|c|c|}
\hline Characteristic & 1 & 2 & 3 & 4 & 5 & 6 \\
\hline Anaerobic growth & + & + & - & + & - & + \\
\hline Catalase & + & - & + & - & + & + \\
\hline Oxidase & + & + & + & - & - & + \\
\hline Nitrate reduction & + & + & - & $\mathrm{V}$ & - & - \\
\hline \multicolumn{7}{|l|}{ Hydrolysis of: } \\
\hline Gelatin & $\mathrm{ND}$ & + & - & + & ND & - \\
\hline Starch & + & + & $\mathrm{ND}$ & - & + & + \\
\hline Urea & - & - & - & - & + & - \\
\hline \multicolumn{7}{|c|}{ Acid produced from: } \\
\hline L-Arabinose & + & + & + & - & + & - \\
\hline D-Cellobiose & ND & + & $\mathrm{V}$ & - & + & - \\
\hline D-Fructose & $\mathrm{ND}$ & + & + & $\mathrm{V}$ & + & - \\
\hline Inulin & - & + & $\mathrm{V}$ & - & ND & - \\
\hline Lactose & + & + & $\mathrm{V}$ & - & + & + \\
\hline Maltose & + & + & + & - & + & $\mathrm{W}$ \\
\hline D-Mannitol & + & + & + & + & + & - \\
\hline D-Raffinose & + & - & - & - & ND & - \\
\hline L-Rhamnose & - & + & + & - & + & - \\
\hline Salicin & + & - & - & - & + & + \\
\hline D-Sorbitol & + & - & - & - & - & + \\
\hline D-Xylose & - & - & - & - & + & $\mathrm{w}$ \\
\hline $\begin{array}{l}\text { DNA G + C } \\
\text { content }(\mathrm{mol} \%)\end{array}$ & 54.0 & $43-46$ & $50-52$ & $42-43$ & $47-49$ & 48.1 \\
\hline
\end{tabular}

lactose, melibiose, sucrose, raffinose, starch, gentiobiose, gluconate and D-turanose are assimilated. $\mathrm{N}$-acetylglucosamine and maltose are poorly assimilated. Erythritol, arabinose, L-xylose, adonitol, fructose, mannose, sorbose, rhamnose, dulcitol, inositol, mannitol, sorbitol, trehalose, inulin, melezitose, glycogen, xylitol, D-lyxose, tagatose, fucose, arabitol, caprate, adipate, malate, citrate, phenylacetate and 2-ketogluconate are not utilized. The major quinone system is MK-7. The DNA G $+\mathrm{C}$ content is $48.1 \mathrm{~mol} \%$. The fatty acids comprise anteiso- $\mathrm{C}_{15: 0}(56.4-57.1 \%)$, iso- $\mathrm{C}_{16: 0}$ (13.0\%), anteiso- $\mathrm{C}_{17: 0}(7.9-8.1 \%)$, iso- $\mathrm{C}_{15: 0}(5.7-5.8 \%)$, $\mathrm{C}_{16: 0}(4.0-4.4 \%), \mathrm{C}_{15: 0}(3.8-4.1 \%)$, iso- $\mathrm{C}_{14: 0}(2.6 \%)$, iso$\mathrm{C}_{17: 0}(1.9-2.1 \%)$ and $\mathrm{C}_{14: 0}(0.8 \%)$.

The type strain, $A 35^{\mathrm{T}}\left(=\mathrm{IAM} 15291^{\mathrm{T}}=\right.$ CCTCC AB206026 ${ }^{\mathrm{T}}$ ), was isolated from coastal soil from Chiba, Japan.

\section{References}

Ash, C., Priest, F. G. \& Collins, M. D. (1993). Molecular identification of rRNA group 3 bacilli (Ash, Farrow, Wallbanks, and Collins) using a PCR probe test. Proposal for the creation of a new genus Paenibacillus. Antonie van Leeuwenhoek 64, 253-260.

Chung, Y. R., Kim, C. H., Hwang, I. \& Chun, J. (2000). Paenibacillus koreensis sp. nov., a new species that produces an iturin-like antifungal compound. Int J Syst Evol Microbiol 50, 1495-1500.

Felsenstein, J. (1985). Confidence limits on phylogenies: an approach using the bootstrap. Evolution 39, 783-791.

Kimura, M. (1980). A simple method for estimating evolutionary rates of base substitutions through comparative studies of nucleotide sequences. J Mol Evol 16, 111-120.

Marmur, J. (1961). A procedure for the isolation of deoxyribonucleic acid from microorganisms. J Mol Biol 3, 208-218.

Saitou, N. \& Nei, M. (1987). The neighbor-joining method: a new method for reconstructing phylogenetic trees. Mol Biol Evol 4, 406-425.

Shida, O., Takagi, H., Kadowaki, K., Nakamura, L. \& Komagata, K. (1997). Transfer of Bacillus alginolyticus, Bacillus chondroitinus, Bacillus curdlanolyticus, Bacillus glucanolyticus, Bacillus kobensis, and Bacillus thiaminolyticus to the genus Paenibacillus and emended description of the genus Paenibacillus. Int J Syst Bacteriol 47, 289-298.

Stackebrandt, E. \& Goebel, B. M. (1994). Taxonomic note: a place for DNA-DNA reassociation and $16 \mathrm{~S}$ rRNA sequence analysis in the present species definition in bacteriology. Int J Syst Bacteriol 44, 846-849.

Swofford, D. L. (1998). PAUP ${ }^{*}$ : Phylogenetic analysis using parsimony (* and other methods), version 4. Sunderland, MA: Sinauer Associates.

Thompson, J. D., Higgins, D. G. \& Gibson, T. J. (1994). ClUSTAL W: improving the sensitivity of progressive multiple sequence alignment through sequence weighting, position-specific gap penalties and weight matrix choice. Nucleic Acids Res 22, 4673-4680.

Xie, C.-H. \& Yokota, A. (2003). Phylogenetic analyses of Lampropedia hyalina based on the 16S rRNA gene sequence. J Gen Appl Microbiol 49, 345-349.

Xie, C.-H. \& Yokota, A. (2006). Reclassification of [Flavobacterium] ferrugineum as Terrimonas ferruginea gen. nov., comb. nov., and description of Terrimonas lutea sp. nov., isolated from soil. Int J Syst Evol Microbiol 56, 1117-1121.

Yoon, J.-H., Seo, W.-T., Shin, Y.-K., Kho, Y.-H., Kang, K.-H. \& Park, Y.-H. (2002). Paenibacillus chinjuensis sp. nov., a novel exopolysaccharide-producing bacterium. Int J Syst Evol Microbiol 52, 415-421. 